\title{
Coletivo em Silêncio: o encontro que cria um corpo político e produz vida
}

\author{
Coletivo em Silêncio: the encounter that creates a political body and \\ produces life
}

\section{Coletivo em Silêncio: el encuentro que crea un cuerpo político y produce vida}

\author{
Paula Gorini Oliveira ${ }^{1, a}$ \\ paulagorini@gmail.com | https://orcid.org/0000-0003-0264-8452 \\ ${ }^{1}$ Universidade do Estado do Rio de Janeiro, Faculdade de Comunicação Social, Programa de Pós-Graduação em \\ Comunicação. Rio de Janeiro, RJ, Brasil. \\ a Doutorado em Comunicação pela Universidade do Estado do Rio de Janeiro.
}

\section{RESUMO}

Este ensaio é um recorte de uma pesquisa mais ampla, a pesquisa de tese que observa a produção do corpo político como parte da manifestação das lutas contemporâneas. Nesse recorte, apresenta-se um relato de experiência, a partir de minha observação participante em um coletivo feminista de arte e educação, de luta antipunitivista e pelo desencarceramento - o Coletivo em Silêncio. A narrativa do trabalho apresenta também depoimentos, poesias e entrevistas concedidas à autora por mulheres atingidas pelo sistema prisional e de justiça, mulheres que foram historicamente e socialmente estigmatizadas como pessoas que não servem à sociedade e por isso podem ser descartadas. Este trabalho, que assume um caráter ensaístico, procura tornar evidentes estratégias de resistência através de práticas comunicativas e da expressão artística, e, por fim, criar espaço para que as falas dessas mulheres ressoem e possam ser escutadas.

Palavras-chaves: Práticas interdisciplinares; Corpo político; Comunicação; Arte; Participação social.

\section{ABSTRACT}

This essay is an excerpt from a broader research, the thesis research that looks at the production of the political body as part of the manifestation of contemporary struggles. In this framework, a narrative of experiences is presented, based on my participant observation in a feminist collective of art and education, concerned with anti-punitive and de-incarceration agenda - Coletivo em Silêncio. The narrative also includes testimonies, poetry and interviews with women who were affected by the prison and justice system, women who were historically and socially stigmatized as people who don't fit into the society and, therefore, can be discarded. This essay seeks to give visibility for practices of communication and artistic expression as strategies of resistance and, finally, set up spaces for those speeches to be resonated and heard.

Keywords: Interdisciplinary practices; Political body; Communication; Art; Social participation. 


\section{RESUMEN}

Este ensayo es un extracto de una investigación más amplia, la investigación de tesis que analiza la producción del cuerpo político como parte de la manifestación de las luchas contemporáneas. En esta sección se presenta un relato de experiencia, basado en la observación participante en un colectivo feminista de arte y educación, anti-punitivo y contra el encarcelamiento - Coletivo em Silêncio. La narrativa de esta obra también incluye testimonios, poesía y entrevistas dadas a la autora por mujeres afectadas por el sistema penitenciario y judicial, mujeres que fueron histórica y socialmente estigmatizadas como personas que no sirven a la sociedad y, por tanto, pueden ser descartadas. El trabajo, que asume un carácter ensayístico, busca evidenciar estrategias de resistencia a través de la comunicación y la expresión artística y, finalmente, criar espacios para que sus discursos resuenen y puedan ser escuchados.

Palabras-claves: Prácticas interdisciplinarias; Cuerpo político; Comunicación; Arte; Participación social.

\section{Contribuição dos autores:}

Concepção e desenho do estudo: Paula Gorini Oliveira.

Aquisição, análise ou interpretação dos dados: Paula Gorini Oliveira.

Redação do manuscrito: Paula Gorini Oliveira.

Revisão crítica do conteúdo intelectual: Paula Gorini Oliveira.

Declaração de conflito de interesses: não há.

Fontes de financiamento: Fundação de Amparo à Pesquisa do Estado do Rio de Janeiro.

Considerações éticas: não há.

Agradecimentos/Contribuições adicionais: não há.

Histórico do artigo: submetido: 10 mar. 2021 | aceito: 9 jun. 2021 | publicado: 30 jun. 2020.

Apresentação anterior: Este trabalho é um recorte da tese "Corpo político e disputas em rede: discursos, performatividades e dissenso nas lutas políticas contemporâneas" (2020).

Licença CC BY-NC atribuição não comercial. Com essa licença é permitido acessar, baixar (download), copiar, imprimir, compartilhar, reutilizar e distribuir os artigos, desde que para uso não comercial e com a citação da fonte, conferindo os devidos créditos de autoria e menção à Reciis. Nesses casos, nenhuma permissão é necessária por parte dos autores ou dos editores. 


\section{INTRODUÇÃO}

Este ensaio é um recorte de uma pesquisa maior, a pesquisa de tese intitulada Corpo político e disputas em rede: discursos, performatividades e dissenso nas lutas políticas contemporâneas (2020). Neste recorte, eu conto a história de um encontro, aliás, reencontro entre mim, jornalista, pesquisadora e ativista, e Valéria, poetisa, ativista e egressa do sistema prisional. Esse reencontro é costurado por duas experiências distintas (e convergentes): a primeira em 2003, quando eu finalizava minha graduação em jornalismo e era estagiária repórter do Núcleo de Educação e Comunicação Comunitária (NECC) das Faculdades Integradas Hélio Alonso (Facha), que me levou à realização de um vídeo-carta produzido com as artesãs e internas da Penitenciária Talavera Bruce. A segunda experiência se dá muitos anos depois, agora como participante do Coletivo em Silêncio, coletivo feminista de arte e educação que trabalha com mulheres e famílias atingidas pelo sistema prisional e de justiça, que me levou a uma oficina-instalação de bordados produzida no Museu Penitenciário do Estado do Rio de Janeiro (Frei Caneca).

O objetivo deste trabalho é relatar, através da narrativa de experiências e de observação participante no movimento social voltado para a luta antipunitivista e o desencarceramento, quais estratégias de comunicação e de sensibilização pela arte participam daquilo que reconhecemos como produção de vida. Ou seja, a partir de um entendimento da saúde de forma integrada, relacionada aos aspectos sociais, culturais e históricos, que garantem a manutenção da vida, e não apenas a prevenção à enfermidade. A partir também de um olhar político para corpos que foram historicamente estigmatizados como impotentes, inúteis e dispensáveis ao sistema social - corpos silenciados e adoecidos de suas potências de se comunicar e se expressar para/com o mundo.

Assim, este trabalho, que se vale de uma escrita implicada, em que a autora participa dos próprios acontecimentos observados numa produção narrativa afetiva, é também uma forma de contribuir para que esses corpos silenciados ganhem maior território de escuta. Na construção metodológica da pesquisa foram incluídos trechos de entrevistas concedidas à autora por duas mulheres participantes do Coletivo em Silêncio: Valéria Mello, egressa do sistema prisional e ativista; e Mhyrna Boechat, psicóloga do Degase (Departamento Geral de Ações Socioeducativas) e ativista. Há ainda trechos de depoimentos retirados do documentário Mãos à arte (2003), de forma a compor a narrativa que aqui se apresenta, em um breve relato sobre o desenvolvimento profissional, artístico e comunicativo de mulheres que foram atingidas pelo sistema prisional, com enfoque na arte e na cultura. Um olhar de lupa para o aspecto da arte e dos processos criativos como pulsões sociais transformadoras. Este ensaio é atravessado pelo debate teórico que concerne às questões raciais e de gênero e pela produção de um corpo político que resiste na história de silenciamento e castigo (sistema punitivista), que se ressignifica em práticas político-poéticas.

\section{O COLETIVO EM SILÊNCIO}

O Coletivo em Silêncio é um coletivo feminista formado por artistas, ativistas, psicólogas, bailarinas, advogadas, arquitetas, bordadeiras, pesquisadoras, enfim, mulheres com formações diversas. Dedica-se ao acolhimento, ao desenvolvimento de capacidades técnicas e à sensibilização estética de mulheres e famílias atingidas pelo sistema criminal e de justiça. Fala-se em 'mulheres atingidas', porque o coletivo trabalha com a ideia de que o sistema prisional é herança de um passado colonial e escravocrata, e que, portanto, as pessoas que passam por esse sistema foram 'atingidas' por uma estrutura social colonialista, excludente e racista.

O foco de trabalho do coletivo é as mulheres, porque o coletivo entende que elas são as mais atingidas pelo sistema patriarcal e racista. Quando presas, cumprem, por vezes, pena por associação ao tráfico ${ }^{i}$, não

\footnotetext{
i A maior parte das mulheres que cumprem pena foi condenada por tráfico de drogas, 63\% da população carcerária feminina, segundo dados do Levantamento Nacional de Informações Penitenciárias - Infopen (BRASIL, 2016).
} 
raro por associação de cunho afetivo e emocional com homens (o marido, o irmão). Quando livres, mas ainda assim atingidas, são as esposas e as mães que mantêm a produção de vínculos afetivos com os homens internos (presos), garantindo, entre outras coisas, a produção e manutenção de vida desses homens. E, quando se fala em 'sistema prisional e de justiça', entende-se que o sistema prisional não se resume à cadeia, mas estende-se aos processos jurídicos que muitas vezes operam injustiças - o que engloba a precariedade da assistência jurídica, de defensores públicos, o uso quase nulo de penas alternativas, de regimes abertos ou semiabertos -, questões que atravessam não apenas o trabalho do Coletivo em Silêncio, mas de todos os coletivos e movimentos sociais que trabalham pelo 'desencarceramento' e pela reforma prisional.

Meu encontro com o Coletivo em Silêncio se dá por muitos outros encontros, como tentarei demonstrar ao longo do texto - que é escrito a partir de uma montagem de referências a esses vários encontros.

Eu trabalhava como produtora no Ponto de Cultura Espaço Panorama (Festival Panorama de Dança), em 2011, quando a bailarina e coreógrafa Paula Maracajá foi convidada pelo Ponto de Cultura para dar um curso de corpo e movimento na Penitenciária Talavera Bruce. A Penitenciária T.B. foi o local onde produzi um vídeo documentário que, depois, se tornou objeto do meu trabalho de conclusão de curso em jornalismo, em 2003, o Mãos à arte, conforme comentado anteriormente. Voltar lá fazia parte de um encontro com meu passado, com minha formação profissional e humana. Um investimento pessoal num sonho de um projeto de comunicação social que eu havia vivido de forma intensa, mas que há muito tinha sido relegado a um arquivo de memórias, e que ali se tornara mais uma vez vivo em meu corpo. Eu precisava voltar lá.

No caminho de volta, eu e Paula fomos conversando de Bangu até a Urca (nosso transporte foi facilitado pela Universidade Federal do Estado do Rio de Janeiro - UniRio) e depois seguimos por mais longas horas conversando. A experiência do trabalho corporal na penitenciária fez Paula Maracajá reestruturar seus projetos artísticos, profissionais e de vida em direção ao trabalho com as mulheres internas e egressas do sistema prisional, o que culminou na fundação do Coletivo em Silêncio, em parceria com outras mulheres profissionais da área de dança. Fechando o ciclo de encontros, em 2019, já como colaboradora do coletivo, eu tive o reencontro mais inusitado, com Valéria Mello, poetisa autora do livro Portão azul (2003).

Conheci Valéria, quando era ainda estudante de jornalismo, na minha primeira ida à Penitenciária T.B., em 2003. Em setembro daquele ano, Valéria lançou seu livro de poesias Portão azul, durante um evento que aconteceu na Universidade Candido Mendes, no centro da cidade do Rio de Janeiro. Era um seminário sobre direitos humanos e sistema prisional, organizado pela Faculdade de Direito, em parceria com o Setor de Responsabilidade Social da Petrobras. Valéria, que estava cumprindo pena na T.B., Complexo Penitenciário de Gericinó, em Bangu, teve autorização para sair do presídio durante dois dias para fazer o lançamento de seu livro. Ela participou do seminário como convidada palestrante, falou para um auditório cheio e depois teve uma tarde de autógrafos na sala de recepção do auditório.

À época, eu ainda era estudante de jornalismo da Facha e fazia estágio como repórter da TV Facha Comunitária, atividade do NECC. Como parte dessas atividades, havíamos sido convidados para fazer a documentação sobre a inauguração do projeto Mãos à arte, uma cooperativa de artesanato inaugurada também em 2003, dentro do Talavera Bruce. Vale notar que o documentário faz menção ao nome da cooperativa.

Voltemos um pouco mais no tempo, alguns meses antes do seminário. O NECC era coordenado pelo professor Nailton de Agostinho Maia, que, ao receber o convite para registrar a inauguração da cooperativa de artesanatoii, propôs fazer um documento audiovisual em formato de 'vídeo-carta', entre as internas

ii Além do registro audiovisual, haveria uma exposição com o trabalho das internas artesãs no seminário de direitos humanos da Candido Mendes. Tanto a publicação do livro Portão azul quanto a exposição de artesanato foram patrocinadas e incentivadas pelo Setor de Responsabilidade Social da Petrobras. 
(do sistema prisional) e o público externo, que teria acesso à exposição dos trabalhos. A vídeo-carta foi produzida com base na ideia de 'comunicação participativa', que implicou a participação das internas nas decisões sobre a gravação, edição e montagem de suas mensagens, de sua 'comunicação', preceito básico de produção da 'comunicação comunitária', com a qual o NECC trabalhava. iii

Assim, a ideia era produzir um documento audiovisual que registrasse os trabalhos das internas artesãs combinado aos depoimentos sobre o processo de trabalho do artesanato. Os depoimentos tinham uma intenção de mensagem, como numa carta, a ser enviada ao público externo - o público presente no seminário de direitos humanos e sistema prisional. Nos dias do evento, havia uma televisão passando a 'vídeo-mensagem' das internas em looping, ao lado da mesa de exposição, e uma 'vídeo-cabine ${ }^{\text {iv }}$ montada pela equipe do NECC. As pessoas que visitaram a exposição e/ou compraram os artesanatos puderam gravar uma mensagem em reposta às internas, diretamente para a câmera, pelo dispositivo da 'vídeo-cabine', completando assim o ciclo da mensagem.

Valéria também foi uma das mulheres com quem conversamos durante as visitas ao Talavera, não como artesã, mas como parte desse grupo de mulheres que haviam ressignificado suas vidas na prisão pela interseção com o trabalho artístico e criativo. O livro Portão azul foi publicado pelo Centro de Pesquisas da Petrobras e lançado no mesmo evento da exposição dos artesanatos produzidos pelas internas artesãs. Sobre o Mãos à arte, Valéria versa:

Foram-se os tempos perdidos/ Confiante em nosso saber/ Confiante em nosso aprender/ Buscando aperfeiçoamento/ Não pro tempo remido/ Porque o que éfeito agora/É mostrado ao mundo lá fora/ O contato com pessoas diferentes/ Que valorizam o trabalho da gente/ No resgaste da nossa moral/ E garantindo o crescimento/ Da oficina de artesanato/ Do mais novo centro cultural. (MELLO, 2003, p. 41)

O 'portão azul' era o portão de entrada da Penitenciária Talavera Bruce, que acabou se tornando não apenas o título do livro de Valéria, mas um símbolo maior de sua 're-existência'. O livro lhe deu a possibilidade de sonhar fora da prisão e o portão azul se tornou uma marca a ser ultrapassada em sua história pessoal, um símbolo de liberdade e de um novo recomeço: "Tudo de errado que aqui aprendi/ Naquele portão de cor azul os deixarei/ Para renascer no novo tempo/ Na bagagem somente levarei/ Minhas poesias/ Que aqui criei" (MELLO, 2003, p. 10).

Eu reencontrei Valéria dezesseis anos após nosso primeiro encontro, no Museu Penitenciário do Estado do Rio de Janeiro. O Coletivo em Silêncio havia sido convidado para a celebração da semana dos museus, a fim de colaborar com objetos, memórias e registros sensíveis e estéticos produzidos pelas mulheres que participavam do coletivo. Em um trecho do Diário de campo, utilizado como parte da metodologia de pesquisa da tese, falo um pouco sobre minha experiência na ida ao museu:

Era uma manhã quente e nublada, quando atravessei a rua Carmo Neto, no Estácio, Rio de Janeiro, em direção ao antigo Complexo Penitenciário da Frei Caneca, implodido em 2010. Primeiro presídio do Brasil, conta a história que demorou vinte anos para ser construído. O complexo elevado no centro da cidade do Rio jaz agora em ruínas entre muros, longe da vista de seus moradores, e guarda um museu, em seu antigo centro administrativo. A atmosfera ao redor da construção é densa e pode ser sentida ao se aproximar da porta

iii A ‘comunicação comunitária' parte do princípio de que quem 'comunica' não é o jornalista, repórter ou especialista, mas a própria pessoa que deseja expressar sua singularidade, sua 'voz' através dos recursos técnicos de comunicação. O papel do jornalista, repórter ou especialista é facilitar esse processo, fazendo na prática uma comunicação 'social'. Em outras palavras, é uma comunicação 'alternativa' e crítica à grande mídia e aos processos hegemônicos de produção de comunicação.

iv Uma cabine fechada é colocada com uma câmera inserida em uma de suas paredes e um microfone do tipo boom, que capta o som ambiente, criando um canal de áudio a mais, além do canal direcional do microfone da câmara. Esse dispositivo facilita ao interlocutor fazer sua fala sem a mediação humana, o que promove maior liberdade na expressão de suas ideias. Não há tempo mínimo nem tempo máximo, o botão de gravar é acionado quando a pessoa entra na cabine e pausado quando a pessoa sai. O fato de só aparecer a lente da câmara, pelo buraco feito na parede da cabine, também permite que o interlocutor se sinta mais à vontade diante da câmera. 
de entrada. Afinal, quanta memória e quanta história cabem nessas ruínas e nas paredes que restam em pé? A história que permeia a atmosfera é de tristeza, dor e silenciamento. Um acervo é feito de memória e esquecimento, já dizia Paul Ricoeur. Há as memórias que serão enquadradas pela historiografia tradicional e as que serão apagadas. O Museu Penitenciário da Frei Caneca apaga a memória das pessoas que lá viveram ou morreram, em seus cárceres ou [no] hospital psiquiátrico. Ali não há protagonistas, apenas coadjuvantes. Ou melhor, o protagonismo é feito por parte dos agentes penitenciários e da SEAP (Secretaria de Estado de Administração Penitenciária), institucionalizado, hermeticamente fechado. Sobre a história e memória dos presos que por ali passaram, resta apenas o protagonismo dos objetos ilícitos por eles produzidos. Armas brancas, canetas de tatuagem, objetos ocos que servem para guardar celulares escondidos. No corredor central do museu, pende do teto uma "teresa", escada de fuga feita de lençóis e lascas de madeira. Nas paredes também podem ser vistas fotos de agentes uniformizados e presos e presas trabalhando nas lavanderias e cozinhas do complexo penitenciário.

Em destaque está a sala da direção, uma sala reconstruída do antigo e primeiro diretor da ala psiquiátrica, dr. Heitor Castilho. Decorada com pesados móveis de madeira, uma estante de remédios e outra de livros, a sala traz ainda uma homenagem ao médico, um busto esculpido em bronze, sua foto na parede, seu currículo, e sua visão como diretor. Entrar na sala deixou meus pelos arrepiados. Mas antes mesmo de me concentrar em textos e fotos que o museu traz em suas paredes, uma surpresa. Do outro lado da mesa de bordados, montada pela instalação Por um fio, do Coletivo em Silêncio, está Valéria Mello. Poetisa que conheci em 2003, na Penitenciária Talavera Bruce, autora do livro Portão azul. (GORINI, 2020, p. 233-234)

O Museu Penitenciário da Frei Caneca não parece representar os presos, mas os agentes penitenciários; tudo remete a eles, dos objetos ilícitos encontrados por eles aos registros dos campeonatos esportivos promovidos entre os agentes. Sobre o universo e o cotidiano dos presos, eles são retratados sempre em servidão, na cozinha, na construção de novos presídios. Os objetos que protagonizam suas histórias apenas relembram as marcas da ilegalidade, objetos proibidos, escadas de fuga etc.

\section{MULHERES QUE ESTÃO POR UM FIO}

A oficina-instalação de bordados Por um fiov , que o Coletivo em Silêncio levou para o museu penitenciário, consiste numa grande mesa de bordados que proporciona o encontro entre mulheres com diferentes experiências de vida, atingidas ou não pelo sistema prisional. Mulheres que, enquanto se sentam à mesa para bordar imagens e palavras relativas ao universo feminino, costuram também suas histórias pessoais, entrelaçam experiências e produzem vida. Uma das instrutoras de bordado, Mhyrna Boechat, psicóloga (do Degase), professora e membro do coletivo desde 2015, assim descreve a oficina:

$\mathrm{O}$ ato de bordar, de tecer, é uma prática do feminino ancestral, uma antiga expressão criativa realizada coletivamente. O movimento das mãos encarna a criação em ato e ativa forças de transformação. Ao entrelaçar agulhas e linhas, vão se contornando bordas, continentes das emoções, ressignificando histórias e sonhos. A prática de articular gestos e palavras, em linhas e prosa poética, promove a criação de territórios existenciais e de novas formas de relação consigo mesmo e com o mundo.

Queremos construir um acervo de trabalhos feitos à mão que reúna a memória coletiva do feminino, pela arte e pela potência micropolítica de transformação do bordado. As linhas e tecidos, como linguagem e expressão, como resgate às técnicas ancestrais e à memória cultural, promovem encontros, reencontros, viagens, constrói saberes. A figura das bordadeiras, em seu gesto poético cotidiano, nas rodas de prosas, na composição pelo olhar e pelo tato, remonta o trabalho manual coletivo, convoca a potência do encontro com o outro por meio das trocas de poesias, desenhos, cores e palavras, em um espaço de ensinar e aprender. ${ }^{\mathrm{v}}$

\footnotetext{
v A instalação artística Por um fio teve sua primeira edição em outubro/novembro de 2018, durante o Festival Panorama, na antiga sede do festival, na Lapa. O Coletivo em Silêncio foi convidado pelo festival para participar com uma residência artística (que previa a facilitação de um espaço de trabalho e de verba para compra de materiais, alimentação e transporte).

vi Este texto foi escrito por Mhyrna Boechat e utilizado pelo coletivo nos materiais de divulgação da instalação artística, durante o Festival Panorama 2018.
} 
Os atos de tecer e de bordar como meios de convocar a potência do encontro foram também o motivo pelo qual o Por um fio teve sua segunda edição no Museu Penitenciário do Estado do Rio de Janeiro. A ideia era possibilitar que esses encontros acontecessem dentro do prédio que abriga o acervo da história dos cárceres brasileiros, desde os tempos coloniais, para também colaborar para uma crítica política-poética.

No dia de minha visita pude observar que, para as mulheres egressas participantes, não foi fácil estarem presentes no local, especialmente para as que haviam cumprido pena no Complexo Penitenciário Frei Caneca, local onde se situa o museu. A instalação e a oficina de bordados permaneceram no museu durante duas semanas, e o coletivo continuou se reunindo na elaboração de uma devolutiva ao museu, com proposta de inserção de objetos, documentos, artesanatos produzidos pelas internas e egressas do sistema prisional. Um dos documentos entregues ao acervo do museu na devolutiva do Coletivo em Silêncio foi o livro de Valéria, Portão azul.

O texto escrito por Mhyrna consegue englobar muitas perspectivas sobre a instalação Por um fio, e foi também por isso que a procurei para gravar um depoimento sobre a experiência dela com o coletivo. Mhyrna conta que foi chamada para participar do espetáculo Poros, em 2015, que aconteceu nos jardins do Parque Lage como a primeira ação pública do Coletivo em Silêncio, durante o Festival Panorama 2015. Por conta de sua experiência como psicóloga dentro do sistema socioeducativo (com jovens menores de 18 anos), Mhyrna fez um trabalho de orientação aos bailarinos e atores que participaram da performance, sobre como eram os corpos dentro de uma prisão. Ela diz:

Na verdade, todo o meu trabalho dentro da prisão, ou dentro do sistema socioeducativo, foi de tentar minimizar os efeitos de aprisionamento dentro desses corpos. E naquela experiência era o contrário, eu tentava trazer a experiência de corpos aprisionados para corpos livres. Foi uma coisa super forte, e meio pesado também. Mas me fez pensar em muitas coisas também, sobre a minha profissão... e sobre como meu corpo se modifica também naquele ambiente. Como aprisiona também o corpo dos funcionários. (GORINI, 2020, p. 236) vii $^{\mathrm{vi}}$

Um dos conceitos com os quais o coletivo trabalha é o de 'cárceres corpóreos', cuja fala de Mhyrna nos permite vislumbrar algumas pistas sobre do que se trata. Trabalhar com corpos aprisionados é trabalhar com corpos que são modificados por uma condição externa e contingente ao ato da privação de liberdade, que se dá em cadeias e espaços controlados, cubículos muitas vezes compartilhados, num processo de ‘docilização’ de corpos, como nos fala Michel Foucault (1991).

O controle dos corpos é investigado pelo filósofo francês em sua ampla produção bibliográfica sobre o tema, que depois é absorvido, debatido, apropriado por diversos outros autores. Para Foucault, as relações de poder estão em todas as instâncias, micro e macro, da família ao Estado. No que concerne ao controle sobre os corpos, o principal argumento de Foucault, em Vigiar e punir (1991), é que há um processo de docilização dos corpos dos indivíduos que tem por finalidade fazer com que permaneçam funcionais para a manutenção de relações de poder que se investem sobre os corpos, garantindo a atuação do Estado como agente de decisão sobre a vida, um controle biopolítico. Esse controle começa a se desenvolver a partir da constituição de instituições disciplinares, tais como escola, hospitais psiquiátricos e prisões. Sobre os "corpos dóceis", Foucault explica:

O momento histórico das disciplinas é o momento em que nasce uma arte do corpo humano, que visa não unicamente o aumento de suas habilidades, nem tampouco aprofundar sua sujeição, mas a formação de uma relação que no mesmo mecanismo o torna tanto mais obediente quanto é mais útil, e inversamente. Forma-se então uma política das coerções que são um trabalho sobre o corpo, uma manipulação calculada de seus elementos, de seus gestos, de seus comportamentos. O corpo humano entra numa maquinaria de poder

vii Depoimento concedido para a pesquisa de tese, em conversa gravada após dinâmica realizada no espaço de encontros do coletivo, em junho de 2019. 
que o esquadrinha, o desarticula e o recompõe. Uma "anatomia política", que é também igualmente uma "mecânica do poder", está nascendo; ela define como se pode ter domínio sobre o corpo dos outros, não simplesmente para que façam o que se quer, mas para que operem como se quer, com as técnicas, segundo a rapidez e a eficácia que se determina. A disciplina fabrica assim corpos submissos e exercitados, "corpos dóceis". (FOUCAULT, 1991, p. 127)

A ideia de "corpos dóceis" apresentada por Foucault muito nos auxilia na compreensão sobre a ideia de 'cárceres corpóreos', uma vez que as instituições disciplinares, entre elas o cárcere, a prisão, funcionam como evidências das relações que se estabelecem no social. Como reflexos complexificados do que se produz, enquanto projeto de poder na 'política de coerções' que são sociais e se aplicam a todos, ainda que essas políticas se tornam mais evidentes sobre alguns corpos em particular. Ou seja, se por um lado os 'cárceres corpóreos' se impõem aos corpos encarcerados, por outro há aprisionamentos que se dão sobre todos os corpos, mesmo quando 'livres' - fora dos cárceres institucionalizados.

Um exemplo que aparece no relato sobre o trabalho artístico da oficina-instalação de Por um fio referese aos corpos femininos que se tornam evidentes nas práticas de bordar. Ao relembrar os encontros vividos na primeira edição dessa oficina-instalação, em 2018, Mhyrna fala sobre o processo de trabalho e de como, a partir do próprio processo, se chegou à ideia de ‘cárceres corpóreos' investidos ao corpo feminino:

- [o trabalho acontece com] mulheres afetadas pelo sistema carcerário. E aí a gente trouxe imagens, palavras, que remetiam a esse universo simbólico delas, e meu também. [...] E, aí, a ideia que foi surgindo foi de um aprisionamento para além do sistema prisional, mas um aprisionamento do corpo mesmo. Do corpo feminino. Então, várias pessoas que não tinham sido atingidas pelo sistema também contribuíram, trazendo essa ideia do que poderia ser o corpo feminino, que tipo de aprisionamento, que tipos de liberdades e aprisionamentos esse corpo poderia experimentar.

[eu] - São os cárceres corpóreos?

- Seria a ideia de cárceres corpóreos. (GORINI, 2020, p. 237)

Em seguida, Mhyrna continua falando sobre a proposta estética da oficina-instalação e sobre como se deu o processo de construção dessa atividade a partir do encontro de ideias e fazeres entre mulheres:

- A gente fez no primeiro dia uma experiência, ativando o corpo, a consciência corporal. E depois a gente foi pra mesa pra pensar desenhos. E aí foi uma coisa muito curiosa, porque eu imaginei que viessem palavras e vieram desenhos. E desenhos de corpos femininos. Então $\mathrm{o}$ ato de desenhar coletivamente e de transformar isso em bordado, trançar linhas, bordar esses riscos do corpo, isso foi uma experiência muito forte. Porque a gente tava vivendo um momento tenso politicamente, era um momento do pós-eleição [2018], próximo da eleição. Na iminência de acontecer o que todos temiam. E aí a gente chamou Por um fio. Chama Por um fio, né? Porque a gente pensava que estaria por um fio, estaria em risco toda aquela coletividade feminina. Todo aquele movimento que a gente tava criando ali, a possibilidade de expressão, não só feminina, expressão humana, expressão artística. Então, esse ritual, de reunir pessoas e da gente ficar ali trabalhando, fazendo um trabalho manual, aquilo é muito inconsciente, sabe?, abre muito ao inconsciente. Então, vinham frases, palavras, experiências, emoções... “- Ah, eu aprendi a bordar coma minha avó..."; "- Eu não sei bordar, mas eu costuro coisas”; “- Eu aprendi com a minha mãe”. Então, essa experiência trazia coisas das nossas antepassadas, da nossa ancestralidade feminina. A experiência do bordar, que foi muita apagada pelas roupas, pela industrialização, pela facilidade dos produtos industrializados. (GORINI, 2020, p. 237)

Quando Mhyrna fala sobre o ato de bordar, o trabalho manual como uma forma de se abrir para o inconsciente, me lembro mais uma vez da cooperativa de arte Mãos à arte. Porque uma das características mais fortes que aparece nas falas das mulheres artesãs é sobre como esse trabalho ressignificou suas vidas. Uma delas, Adriana, contou que antes da cooperativa ela era conhecida por seu comportamento agressivo, que lhe rendeu o apelido de 'Mau'. Depois de começar a trabalhar com artesanato, Adriana explicou que não apenas passou a ter um comportamento mais harmônico com suas companheiras de prisão e com as 'guardas', como pôde também sonhar com uma vida melhor fora da prisão. No documentário que apresenta 
todo o processo, produzido como 'projeto experimental' em meu Trabalho de Conclusão de Curso (GORINI; COSTA, 2004) ${ }^{\text {viii }}$, incluímos o registro audiovisual de Adriana lendo uma carta que havia sido escrita para o Gugu (Liberato), que fala sobre seu passado e seus sonhos para o futuro, a pedido dela mesma. Essa carta escrita por ela, que desde a infância e a adolescência sempre viveu em abrigos, reingressando sistematicamente no sistema socioeducativo e depois no sistema prisional, reflete um mundo interior que conecta sua vida presente com futuros imaginados.

O que me parece curioso foi que Adriana quis compartilhar esses sonhos com a nossa equipe de trabalho (NECC), após o término das gravações do vídeo-carta, numa abertura de intimidade e sensibilidade, talvez com a esperança de que nós pudéssemos levar sua mensagem a um público mais amplo e certamente numa busca por empatia. Outra fala que se repetiu nas entrevistas, inclusive na de Adriana, era sobre "ter um pedaço de você lá fora, o que você criou" (GORINI; COSTA, 2004), a ideia de que, apesar de elas terem que permanecer confinadas, a criação delas, o artesanato, poderia ser livre e sair da prisão. E isso, de alguma forma, estabelecia uma relação entre o dentro e o fora do sistema prisional. E mais: que esse pedaço' delas do lado de fora da prisão mostraria à sociedade que elas 'mudaram', que todo ser humano pode mudar - a criação como potência de transformação.

A oficina de artesanato foi uma conquista de algumas presas que havia muito tempo estavam reivindicando esse espaço de trabalho. O artesanato, além de desenvolver capacidades técnicas, é um trabalho manual, criativo, que pode ser terapêutico, diferentemente dos trabalhos institucionalizados dentro dos presídios que utilizam a força de trabalho dos presos de forma exploratória, a baixíssimos salários, sem garantias nem direitos. O espaço de artesanato não prevê direitos nem garantias, nem mesmo salário ${ }^{\text {ix }}$, mas é um espaço de construção coletiva dessas mulheres. Em um dos depoimentos gravados para o vídeo-carta, a artesã que se apresenta como Mila fala assim sobre o espaço Mãos à arte:

A gente não quer que o Mãos à arte fique aqui dentro do Talavera Bruce, a gente quer levar ele pra rua. E a gente vai pedir uma ajuda de vocês, que vocês divulguem isso, que apareça algum empresário, que ao invés de estar mandando cadeado, construindo cadeia, construa um galpão pro ex-presidiário. Para, ao invés de a gente sair e ser aquele ser nocivo que ela [a sociedade] acha que a gente vai sair e vai ser, a gente possa, ao invés de pegar uma pistola, a gente ter um lugar pra desempenhar um trabalho e poder fazer o nosso dinheiro. (GORINI; COSTA, 2004)

Mais uma vez a relação entre o dentro e o fora da prisão, através da prática de artesanato, demonstra a produção de outros mundos possíveis no contexto da criação artística e, acredito, que também da sensibilização pela arte. São corpos políticos que se constroem nessas práticas. A fala de Mila, reproduzida anteriormente, também nos dá pistas para compreender como as práticas punitivistas do sistema prisional (que visam punir, e não 'ressocializar') são práticas problemáticas que necessitam ser revisitadas e combatidas.

Foucault (1991), ao analisar as reformas penitenciárias ocorridas na passagem da Idade Média para Idade Moderna, discute as mudanças nos sistemas de punição ao longo do tempo, especialmente na chegada ao Iluminismo. Inicialmente, temos o "suplício", atos públicos de castigos violentos sobre os corpos dos condenados, realizados por carrascos em praças públicas, para o qual Foucault atribui o caráter de "vingança" dos soberanos. Depois veio a "punição", mediante a privação da liberdade e o confinamento, como um castigo que visa corrigir o comportamento do "criminoso" através de processos mais "humanizados", com julgamentos mais complexificados e alteração das leis penais. No entanto, essa transformação que tinha por objetivo uma "humanização", segundo o autor, é o que delimita o poder sobre os corpos, em que humano

viii O documentário produzido como projeto experimental, em parceria com Uirá Costa, inclui os vídeos ‘mensagem’ e 'resposta' e entrevistas com especialistas.

ix O dinheiro arrecadado com os objetos vendidos retorna às artesãs, como qualquer trabalho autônomo. 
passa a ser o limite em "uma nova 'economia política' do poder de punir" (FOUCAULT, 1991, p. 75). De toda forma, vale observar que, em outra passagem do livro, a "forma-prisão" já estava ativa antes mesmo de a prisão ser institucionalizada. Assim Foucault explica:

\begin{abstract}
A forma-prisão preexiste à sua utilização sistemática nas leis penais. Ela se constitui fora do aparelho judiciário, quando se elaboraram, por todo o corpo social, os processos para repartir os indivíduos, fixá-los e distribuí-los espacialmente, classificá-los, tirar deles o máximo de tempo, e o máximo de forças, treinar seus corpos, codificar seu comportamento contínuo, mantê-los numa visibilidade sem lacuna, formar em torno deles um aparelho completo de observação, registro e notações, constituir sobre eles um saber que se acumula e se centraliza. A forma geral de uma aparelhagem para tornar os indivíduos dóceis e úteis, através de um trabalho preciso sobre seu corpo, criou a instituição-prisão, antes que a lei a definisse como a pena por excelência. (FOUCAULT, 1991, p. 207)
\end{abstract}

Na direção contrária a uma prática punitivista, que substitui a prática do suplício e atualiza a ideia de castigo, o discurso produzido sobre a prisão como espaço de ressocialização de sujeitos apenados se baseia na estruturação de recursos técnicos, emocionais e criativos (escola e educação formal, capacitação técnica e profissional, desenvolvimento artístico e criativo, atendimento jurídico, médico e psicológico) como meio de 'preparar' as pessoas privadas de liberdade para retornarem à sociedade como pessoas livres, após terem cumprido suas penas. Na prática, cria-se uma situação de dependência com o sistema prisional, em que as pessoas condenadas à privação de liberdade, mesmo após terem cumprido suas penas, seguem sendo vistas pela sociedade como criminosas, dificultando seu acesso à educação e ao mercado formal de trabalho, e levando-as, muitas vezes, a retornar recorrentemente ao sistema prisional.

No vídeo-carta Mãos à arte, Mila fala assim: "Às vezes, a pessoa comete um pequeno delito, não conhece ninguém, mas o sistema penitenciário é a melhor faculdade pra quem quer ingressar na vida do crime" (GORINI; COSTA, 2004). Em outro trecho do vídeo, quando Mila apresenta seu trabalho de artesanato, um quadro produzido com sucata e material reciclado, ela traça uma comparação com a vida das mulheres presas: "O lixo, você recicla, fica bonito e é usado. Eu sou um ser humano e perante a sociedade eu não presto pra mais nada. Pra eles eu tinha que ir pro esgoto. O lixo hoje você aproveita, eu, não" (GORINI; COSTA, 2004).

Refletindo sobre essas questões e sobre a ideia de "forma-prisão" preexistente ao sistema penal, observo que "punição" e "ressocialização", apesar de parecerem sugerir ideias opostas, são apenas reflexos de uma mesma lógica que vê $\mathrm{a}(\mathrm{o})$ presa(o) como alguém que está à margem do social (e por isso precisa de "resocialização') e talvez por isso essa ideia também esteja fadada ao fracasso. A meu ver, a única prática possível, no contato que tive com o trabalho com internas e egressas do sistema prisional - 2003, 2011, 2018 e 2019 - é através do desencarceramento e do desenvolvimento de políticas públicas voltadas para o desenvolvimento social. Políticas com finalidade de reparar estruturas historicamente injustas e excludentes, como políticas de educação, formação profissional, assistência jurídica e psicológica, moradia e habitação e ecologia. Ou seja, a reforma que o sistema prisional precisa ter é uma reforma de base na estrutura social e nas divisões de poder. $\mathrm{O}$ crime e o castigo são lados de uma mesma moeda.

\title{
O CASTIGO
}

Volto mais uma vez ao dia em que Valéria saiu para fazer o lançamento de seu livro, em 2003. Como convidada a participar da mesa de debates do evento sobre direitos humanos e sistema prisional, Valéria caminha pelo corredor do auditório lotado, em direção à mesa que estava montada no tablado do teatro e, ao caminhar, Valéria tropeça, se desequilibra, recupera-se e segue andando. Quando ela começa sua fala pública, diz que, ao caminhar pelo corredor, tendo todo espaço disponível para seus passos, seu corpo estranhou a amplitude, acostumado que está a viver em um espaço de 2 x 2 metros, na prisão Talavera 
Bruce. As marcas sociais do controle sobre os corpos encarcerados se apresentam nessa cena como um desvio corporal, um desequilíbrio, que nos fala muito sobre como a experiência do cárcere se dá no corpo. Na poesia 'Trancada', ela fala:

Estou trancada, tudo quero/ Nada posso, tudo é não/ O que quero é andar, não tem lugar/ $\mathrm{O}$ que quero é correr, não posso isso fazer/ O que quero é nadar, não posso, não vejo o mar/ O que quero é sorrir, você não está aqui/ O que quero é voar, não tenho asas para me libertar/ O que quero é te ver, meus olhos ficam "cadê, cadê?"/ estou trancada, não posso nada. (MELLO, 2003, p. 25)

O corpo quer, o corpo pode, mas "trancado" não pode nada, nem andar, nem correr, nem nadar, nem sorrir, nem voar, nem ver. Trancada está a pessoa que teve sua vida privada de liberdade, após condenação penal. Tranca também é a forma como as internas da prisão se referem à 'solitária', que por vezes também é chamada de 'castigo'. Castigo é uma ideia que remete aos tempos do Brasil colonial escravocrata, em que os negros africanos escravizados pelos colonizadores portugueses eram subjugados e submetidos a todo tipo de violência - física, emocional, mental -, torturas e castigos. O castigo era o tronco, as chibatadas, os objetos de tortura, como a mordaça e os grilhões de ferro.

Grada Kilomba (2019), em seu livro Memórias da plantação, apresenta no primeiro capítulo uma reflexão sobre o silenciamento dos sujeitos negros a partir do trauma e da dor física implementada sobre o corpo dos africanos escravizados no período colonial, por torturas e castigos. A autora apresenta a imagem da Escrava Anastácia para desenvolver essa reflexão inicial sobre o uso da mordaça, que Kilomba renomeia como "máscara de silenciamento" (p. 33). Um objeto de tortura utilizado pelos colonizadores sob a justificativa de coibir que os negros escravizados comessem cana-de-açúcar ou cacau durante a colheita e o trabalho de plantio. A máscara ou mordaça "era composta por um pedaço de metal colocado no interior da boca do ‘sujeito negro', instalado entre a língua e o maxilar e fixado por detrás da cabeça por duas cordas, uma em torno do queixo e a outra em torno do nariz e da testa" (KILOMBA, 2019, p. 33).

Ao longo dessa reflexão sobre a mordaça e o silenciamento dos negros, a autora também introduz a ideia de "outridade", relacionada à construção do ego, sendo o "sujeito negro o outro" do sujeito branco. O crime cometido pelo negro escravizado de roubar aquilo que é propriedade do branco (a cana-de-açúcar e o cacau) justifica a estrutura de um ego que se separa do "eu", benevolente e interiorizado como o sujeito branco, e todo o resto, diferente e malévolo, exteriorizado como o sujeito negro. Assim, o "outro" aqui não representa apenas a diferença, mas a negação, o que é ruim, o que deve ser subjugado. A autora explica: "O 'sujeito negro' torna-se então tela de projeção daquilo que o 'sujeito branco' teme reconhecer sobre si mesmo, neste caso: a ladra ou o ladrão violenta(o), a(o) bandida(o) indolente e maliciosa(o)" (KILOMBA, 2019, p. 37).

Ora, Valéria é uma mulher negra. A maioria da população carcerária é negra. Segundo consta no Levantamento Nacional de Informações Penitenciárias (BRASIL, 2016), 64\% da população carcerária é negra. Abaixo, destaco as imagens de dois gráficos retirados desse documento, considerado oficial, produzido por entidades de pesquisa ligadas ao Governo Federal. O primeiro gráfico diz respeito ao quantitativo racial e demonstra que a população total de negros é maior no cárcere que fora dele. No segundo gráfico há informações sobre número de filhos da população carcerária total, numa comparação entre os gêneros femininos e masculinos. 

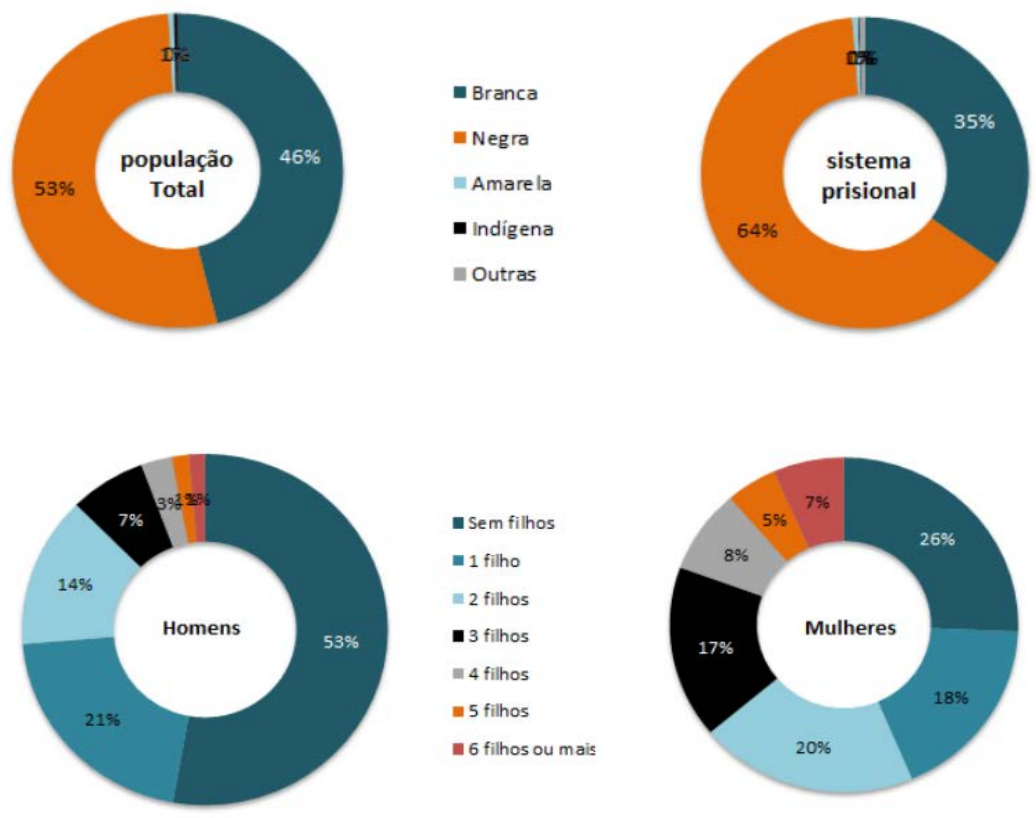

Figura 1 - População carcerária no Brasil.

Fonte: Brasil, 2016, p. 32, 40.

Observando de forma geral os dois gráficos destacados (Figura 1), já que esse não é objeto de minha pesquisa, procuro contextualizar o lugar em que Valéria se encontra e de que lugar se produz a poesia dela. No Brasil, 64\% da população carcerária é negra, proporção maior que a de negros na população total brasileira (53\%); esses números mostram como ainda aplicamos os mesmos códigos de castigos, as mesmas mordaças e torturas sobre a população negra. As mordaças que querem silenciar as palavras dos negros africanos escravizados são ainda contemporâneas e seguem tentando calar bocas como as de Valéria. Em "Reflexões", uma das poesias em que Valéria denuncia a violência do sistema prisional e de suas agentes penitenciárias, o eu lírico fala sobre o processo de silenciamento em seu corpo:

O que querem de mim?/ Não posso sentir dor/ Não posso estudar/ Se estou trabalhando/
Elas vêm implicar/ As guardas deste plantão/ Vivem a me perseguir/ O que fazer? Deixar
de existir?/ Há mais de três meses esperando a sonhada "lili”" / Estou cansada, pedirei
ao diretor para me transferir/ Se eu não conseguir/ A solução que tenho é fugir/ Fugir
do "T.B.", de onde eu fugi/ É muito mais fácil/ Fugir pra um lugar/ Onde as guardas
daqui/ Não vão me achar/ Quero pagar, esse crime, essa dívida/ Mas não posso aceitar/
A cada três dias perseguida/ Fui proibida de falar/ Logo serei coibida até de andar/ É
muita tortura, não aguento mais/ Preciso ir embora desse lugar/ Estou sendo incentivada/
Assim a pensar/ Eu já roubei, não quero matar/ Sou poetisa, meu dever é amar. (MELLO,
2003, p. 29-30)"

Nos versos da poesia de Valéria, vemos mais uma vez o silenciamento investido sobre esse corpo ("fui proibida de falar/ logo serei coibida até de andar") e também o gesto de resistência ("sou poetisa, meu dever é amar”), que se expressa na poesia, na criação artística. Para Grada Kilomba, o silenciamento do sujeito negro diz respeito não apenas ao gesto de falar, mas principalmente ao gesto de ouvir. Falar está vinculado ao ouvir, numa situação dialética em que, para se falar, é preciso que essa fala seja escutada. Para Kilomba, a "máscara de silenciamento" serve como um mecanismo de proteção do ego (dos sujeitos brancos) para retirar de si a responsabilidade sobre o racismo que é operado cotidianamente, de forma estrutural. Ela explica: 


\begin{abstract}
A máscara, portanto, levanta muitas questões: por que deve a boca do ‘sujeito negro’ ser amarrada? Por que ela ou ele tem de ficar calada/o? O que poderia o 'sujeito negro' dizer se ela ou ele não tivesse sua boca tapada? E o que o 'sujeito branco' teria de ouvir? Existe um medo apreensivo de que, se o ‘sujeito' colonial falar, a/o colonizadora/or terá de ouvir. Seria forçada/o a entrar em uma confrontação desconfortável com as verdades da/o 'Outra/o'. Verdades que têm sido negadas, reprimidas, mantidas e guardadas como segredos. Eu gosto muito deste dito ‘mantido em silêncio como segredo'. Essa é uma expressão oriunda da diáspora africana e anuncia o momento em que alguém está prestes a revelar o que se presume ser um segredo. Segredos como a escravização. Segredos como o colonialismo. Segredos como o racismo. (KILOMBA, 2019, p. 41, grifos no original)
\end{abstract}

Interessante observar a fala de Kilomba sobre os segredos, sobre aquilo que não pode ser dito, revelado, como o racismo. Eu acrescento: segredos como o do machismo. E, se o Coletivo em Silêncio trabalha, silenciosa mas ativamente, na luta contra o encarceramento, tendo a mulher e o feminino como foco de transformação, é porque as mulheres são duplamente atingidas pelo sistema racista e machista da prisão. Elas são atingidas pela lógica punitivista, cujo foco do castigo é inverso à produção de vida; pelo sistema patriarcal, que relega à mulher o papel de 'cuidadora' e 'mantenedora' da família e dos vínculos afetivos.

No gráfico que faz a comparação entre gêneros (Figura 1), no que diz respeito à quantidade de filhos, podemos observar que a população masculina no cárcere é de $53 \%$ sem filhos, enquanto a população feminina no cárcere, sem filhos, é de apenas 26\%. Mais da metade dos homens presos 'não são pais' e mais de três quartos das mulheres presas ‘são mães', segundo o comparativo. Valéria dedica vários de seus poemas aos seus três filhos, outros tantos ao amor e à solidão. Em Justificativa, temos:

Mãe criminosa/ Assim os filhos criou/ o filho não usa drogas/ É estudante e trabalhador/ O pouco que eu ensinei/ Ele almeja ser doutor/ A menina os estudos largou/ Por faltar a mãe ao seu lado/ Que injustiça condenou/ E a caçulinha tão pequenina/ Que sofre com minha ausência/ Nas mãos dos familiares/ Que não tem paciência/ Sofro pedindo a Deus que os guarde/ Com a mãe honesta ao lado/ Muitos filhos/ Da sociedade e da autoridade/ Hoje são criminosos, políticos ladrões/ Para meu orgulho e felicidade/ Os meus três filhos têm/ Honestidade, respeito e educação. (MELLO, 2003, p. 73-74)

Os versos de Valéria refletem o lugar de onde ela fala, de corpos que foram subalternizados por sistemas de exclusão e por mecanismos de silenciamento, que até hoje permanecem e se perpetuam. Eu, que comprei seu livro de poesias em 2003 e o tenho guardado e autografado desde então, encontro nos versos de Valéria a sensibilidade que os muros da prisão e as máscaras de silenciamento não foram capazes de apagar. De certa forma, uso esses versos para dialogar com a alteridade, como um exercício de empatia, já que eles não fazem parte de meu repertório de vida. E peço licença à Valéria para usá-los, uma vez que tenho consciência de que a reescrita dessa história é dolorosa demais para ela. Falo, então, a partir de um encontro, um encontro que demorou 16 anos para ser 're-conhecido', conhecido de novo, numa parceria que hoje, finalmente, ainda que guardadas as diferenças, nos possibilita caminhar juntas por corredores de auditórios lotados, lado a lado, tropeçando e se reerguendo. Valéria me conta, em entrevista ${ }^{\mathrm{xi}}$, que os encontros no Coletivo em Silêncio e o trabalho corporal a fazem "quase" esquecer seu passado no cárcere. "Quase”, ela diz, "nem me lembro que eu passei pelo cárcere, todos os dias”. Assim fala Valéria sobre a experiência junto ao Coletivo em Silêncio:

Esse trabalho corporal trouxe libertação para minha mente, que fiquei num lugar que... totalizando 10 anos, um lugar onde prendem o seu corpo, prendem a sua liberdade de expressão, e isso tumultua o seu pensamento. E quando chegamos aqui [fora da penitenciária] faz com que continuemos com esse tormento. E estar dentro do Coletivo em Silêncio faz com que eu até me esqueça que eu passei pelo cárcere. Por todo um trabalho, tanto manual, como a escrita, como corporal, em gestos, em apresentações, em grupo... a dinâmica... e hoje eu posso falar que eu nem me lembro que eu passei pelo cárcere, todos os dias. (GORINI, 2020, p. 245)

xi Depoimento concedido para pesquisa de tese, em conversa gravada após dinâmica realizada no espaço de encontros do coletivo, em junho de 2019 . 
Nesse mesmo depoimento, ela conta que foi transformada por essas práticas; não apenas as dinâmicas corporais a ajudaram, mas o sentimento de grupo, de pertencimento, de acolhimento a fez se sentir capaz de recomeçar - hoje ela pode ajudar pessoas que chegam ao coletivo, enquanto antes ela só conseguia ver seus próprios problemas. "Antes as pessoas diziam que tinham problemas e eu dizia que tinha também. Agora, dentro do Coletivo em Silêncio eu consigo ter palavras de apoio para essas pessoas que buscam esse apoio em mim" (GORINI, 2020, p. 245). Valéria tem ligação com outro coletivo de que faz parte e é fundadora, o Coletivo Todxs Unidxs, formado por mulheres egressas do sistema prisional que lutam por condições mais humanas para quem está lá dentro.

\title{
CONSIDERAÇÕES FINAIS
}

A coletividade e o encontro entre pessoas são um ponto importante a ser pensado como meio de ativar corpos políticos que se colocam juntos para inventar outras formas de resistir. Mhyrna Boechat, ao falar sobre a questão da coletividade, fala também sobre como esse "estar juntos" de corpos, das mulheres que resistem por um fio às ameaças iminentes externas, é o espaço onde se mobiliza a produção de si:

\begin{abstract}
E quando cai essa barreira consciente também vêm experiências dolorosas, de violência, do sistema, das injustiças sociais. [...] é uma potência clínica no sentido existencial, de troca, de confiança e de criação de vínculo. Produção de mundo, produção de si. Você está ali produzindo a si mesmo. E produzindo o mundo. E quando a gente fala isso não é metáfora. É produzir vínculo, é produzir elo social mesmo. Essa coletividade já é muito política. (GORINI, 2020, p. 245)
\end{abstract}

A história de mulheres que estão por um fio também é interlaçada pelo compartilhamento de experiências de vida, da revisita a passados dolorosos através do gesto ancestral do bordar, em torno de uma mesa em que acolhem e são acolhidas. Esse gesto ressignifica as marcas das memórias de violências institucionais vividas por mulheres atingidas não apenas pelo sistema prisional e de justiça, como também pela violência de Estado. Mães que perderam seus filhos assassinados pela força de Estado policial, nas comunidades do Rio de Janeiro, como o grupo de Mães de Manguinhos e das Bordadeiras da Coroa, que participam do coletivo. Mulheres que convivem diariamente com opressões diversas ainda ativas em nossa sociedade contemporânea, como o racismo e o machismo, e reescrevem seus sonhos no ato de versar e tracejar, num processo de autocuidado e de cura com passado.

Esses são corpos femininos que buscam o desencarceramento subjetivo, sensível e poético na produção do encontro e do prazer da criação. Corpos que ganham contornos políticos porque ativam camadas sociais e ressignificam vidas, através da sensibilização pela arte, numa micropolítica de afeç̧ões. No Coletivo em Silêncio, a produção de vida diz respeito a tudo aquilo que dá contorno para a experiência vivida de cada mulher, suas dores, mas também seus desejos, seus afetos. Afetos aqui entendidos no sentido em que os entendem Gilles Deleuze e Félix Guattari (1995), como uma manifestação de um 'devir'.

A potência que se dá no encontro e na possibilidade de afetação mútua do encontro, que atravessa memórias e histórias em uma mesa de bordado. Que reinventa experiências e transforma marcas de um passado de opressões em gestos criativos de desenhar, de bordar, de versar, e também compartilhar. É nessa direção que pretendo fechar o sentido de 'encontro como produção de vida', que tangencia o argumento deste ensaio. A experiência com a arte, as artesanias, a poesia e o corpo, participa da produção daquilo que estou chamando de corpo político no Coletivo em Silêncio, produzido 'entre' e 'por' mulheres, na resistência aos cárceres corpóreos que nos foram social e historicamente impostos, (de maneira diversa, é claro, e não comparativa). Finalizo, então, este trabalho, com um último poema de Valéria. Em seu Portão azul, os sonhos já estavam traçados em Crianças nas escolas sem muros e grades: 
Escritores em seus livros/ Todos são experientes/ Descobri ser poetisa/ Com tantos problemas na mente/ Críticos, esses são inteligentes/ Nos debates da TV/ Falam de coisas que não sofreram/ Por trás dos muros e grades/ Quem vive vinte e quatro horas sou eu/ Extravaso com caneta no papel,/ Realidade sem gota de mel/ Hoje mostro a vocês,/ É possível na cadeia/ Transformar a incerteza/ Que poesia é verdade/ Escrevendo com clareza/ Aproveito meu debate/ "pense bem, politicagem"/ 'Nossas crianças nas escolas/ No mundo não mais se construirão/ Cidades de grandes muros e grades'. (MELLO, 2003, p. 39, grifo meu)

\section{REFERÊNCIAS}

BRASIL. Ministério da Justiça e Segurança Pública. Departamento Penitenciário Nacional. Levantamento nacional de informações penitenciárias: atualização - junho de 2016. Brasília, DF: Ministério da Justiça e Segurança Pública, 2016. Disponível em: https://www.gov.br/depen/pt-br/sisdepen/mais-informacoes/ relatorios-infopen/relatorios-sinteticos/infopen-jun-2016.pdf/view. Acesso em: 14 jun. 2020.

DELEUZE, Gilles; GUATTARI, Félix. Mil platôs: capitalismo e esquizofrenia. Rio de Janeiro: Editora 34, 1995. v. 1.

FOUCAULT, Michel. Vigiar e punir. 9. ed. Petrópolis: Vozes, 1991.

GORINI, Paula; COSTA, Uirá. Vídeo-carta: uma experiência participativa. 2004. 49 f e 1 DVD (47 min). Monografia (Graduação em Jornalismo). - Faculdades Integrada Hélio Alonso, Rio de Janeiro, 2004.

GORINI, Paula. Corpo político e disputas em redes: discursos, performatividades e dissenso nas lutas políticas contemporâneas. 2020. 268 f. Tese (Doutorado em Comunicação). - Universidade do Estado do Rio de Janeiro, Rio de Janeiro, 2020.

KILOMBA, Grada. Memórias da plantação: episódios de racismo cotidiano. Rio de Janeiro: Cobogó, 2019.

MÃOS à arte. Coordenador: Nailton de Agostinho. Reportagem/edição: Paula Gorini e Uirá Costa. Entrevistas: Adriana, Carla M., Carla P., Daniela, Lila, Lotta, Mila, Simone, Valéria. Produção: Espaço Facha Comunitário/ NECC (Núcleo de Educação e Comunicação Comunitária). Rio de Janeiro: Faculdades Integradas Hélio Alonso (Facha), 2003. 1 DVD (15:46 min).

MELLO, Valéria. Portão azul. Rio de Janeiro: Centro de Pesquisas da Petrobrás, 2003. 